a spoon or such-like article the light is readily produced, and when two such masses are rubbed together a very strong glow is the result.

Colonial Sugar Ref. Co., Ltd., Sydney, N.S.W.

\section{The Wanton Destruction of Rare Visitants to our} Shores.

IN the Zoologist for this month (No. 691) is recorded the destruction and capture of the following rare bird visitants to our shores:-Six crossbills, one goshawk, one flamingo, one little bustard, one great shearwater, one avocet, and two Sclavonian grebes. Is it not time this senseless and unwarrantable destruction of these beautiful creatures ceased? Will you, as the leading scientific journal, lift up your voice against it, and earn the gratitude of every lover of nature?

Rottingdean, Sussex.

E. L. J. RidsDale.

\section{EXPERIMENTS ON THE AUTUMN COLOURING OF PLANTS.}

\section{$\mathrm{T}$}

HOUGH in the course of the present century a good deal has been written as to the causes of the autumn tints of leaves, our knowledge of this subject is still in a very unsatisfactory condition. The following notes may serve to show the nature of some of the principal factors involved.

While engaged on some osmotic experiments in the summer of 1897 , I made the observation that the newlyformed leaves of specimens of Hydrocharis morsus-ranae, which had been placed some days previously in a weak solution of cane-sugar, assumed a rich reddish-brown colour, although otherwise perfectly normal. Further experiments showed that the culture of this plant in solutions of cane-sugar, grape-sugar and fructose constantly has this effect on the colouring of those leaves which are developed during the sojourn of the specimens in these solutions, and that even the leaves which were fully developed before the commencement of the experiments gradually become of the same reddish-brown hue.

This colour is due to the appearance of red cell-sap in the palisade-cells, and in the cells lining the air-chambers of the leaf. A certain number of these cells often contain red cell-sap under normal conditions, especially if the plants are strongly insolated, and the temperature of the water in which they are living is somewhat low ; but under these conditions, the leaves never assume a colour approaching to that of plants cultivated in sugar solutions. If the sugar solutions are changed often enough, the plants remain perfectly healthy for weeks, and multiply rapidly by means of suckers. In one set of experiments I have followed the development during four successive generations.

In specimens of Hydrocharis grown in a good light the leaf-stalks, suckers and roots are usually more or less dotted with red under normal conditions ; but the number of cells containing red cell-sap is very much increased in these parts of the plant, if the specimens are cultivated in a sugar solution, even though the conditions of light and temperature are much less favourable for the production of the red pigment than in the specimens grown in pure water.

Salt solutions and the solutions of organic compounds other than the carbohydrates have no such effect on Hydrocharis, and even among the sugars galactose is entirely without effect. Lactose acts only after a long period, and the effect is even then very slight and is probably due to hydrolysis.

A few experiments with Lemna minor and with Potamogeton perfoliatus in solutions of various sugars not leading to similar results, I should probably have laid the whole subject aside, had not my attention shortly afterwards been drawn to the red-colouring of plants in general by a tour in the Upper Engadine just at a time when the autumnal colouring of the Alpine plants was reaching its climax.

No. I 526 , voL. 59]
There, among the magnificent tints that overspread the mountain slopes, my mind naturally reverted to my laboratory experiments and the possibility of a correlation between the two sets of phenomena suggested itself. Observations and experiments, made upon the spot, led me to the conclusion that there were good grounds for the conjecture that an increase of sugar at the cost of starch might be one of the factors concerned in the formation of the red pigment of those leaves which become red in autumn.

Of such leaves there are two distinct classes. The one set comprises the perennial leaves, and those leaves which, formed during the later part of the summer, remain alive till the following spring or summer. This set of leaves (with the exception of those which die in spring) lose their reddish hues with the return of warmer weather (e.g. holly, ivy). The other set comprises those leaves which fall and die soon after attaining their reddish tints.

Lidforss ${ }^{1}$ has drawn attention to the fact that during the winter the leaves of our native plants are entirely devoid of starch, but contain large quantities of sugar. Without a previous knowledge of Lidforss' paper, I obtained the same results and found that the deciduous leaves at the time they assume their autumn tints contain more sugar and less starch than in midsummer.

The remarkable coincidence of the appearance of red cell-sap with the increase of sugar in autumn and its disappearance in spring at a time when the greater part of the sugar in the leaf is recondensed to starch, together with my observations on Hydrocharis, formed the starting point for a considerable number of experiments on the formation of the red pigment of leaves.

These experiments and observations have led me to conclusions which may be stated broadly thus :-

The red colouring matters of green plants are probably of the nature of glucosides, and are in most cases unions of tannin compounds with sugar.

The chief physical factors in their production are : (a) sunshine, which on the one hand augments assimilation and the production of sugar, and on the other hand accelerates the chemical process leading to the formation of the pigment ; and $(b)$ a low temperature, which prevents the conversion of the sugar into starch. In other words, the red autumnal tints are in great measure the direct result of the autumnal climatic conditions.

It is possible in many plants to produce (red) autumnal tints at any time of the year, by feeding them with glucose.

Generally speaking, this artificial production of red cellsap is possible only where the natural reddening of the leaf has its seat in the mesophyll cells. In cases where the coloration is in the epidermis, experiments with glucose are unsuccessful.

Among plants especially favourable for experiments on the artificial production of red cell-sap, I may mention various species of Lilium (L. Martagon, L. candidum, $L$. umbelliferum), Holly (Ilex aquifolium), various succulent plants, such as Saxifraga crassifolium, and among water-plants, besides Hydrocharis, the different indigenous species of Utricularia.

A full account of these experiments, together with their connection with various phenomena of plant-life, will appear shortly in the Jahrbiicher fïr wissenschaftliche Botanik. E. OVERTON.

\section{THE GREAT CATALOGUE OF BIRDS.}

THE recent issue of the twenty-sixth volume of the "Catalogue of Birds in the British Museum" (the twenty-seventh and concluding volume having been published in advance in 1895) brings to an end a
1 Botan. Centralblatt, Bd. 68. p. $33-44$ (1896)
2 "Catalogue of the Platalex. Herodiones, Steganopodes, Pygopodes, Bowdler Sharpe and W. R. Ogilvie-Grant. (London, I898.) 